\title{
THE VOLATILITY OF A HALF-COOKED BOUILLABAISSE: REBEL-MILITARY INTEGRATION AND CONFLICT DYNAMICS IN THE EASTERN DRC
}

\author{
MARIA ERIKSSON BAAZ AND JUDITH VERWEIJEN*
}

\begin{abstract}
In early 2012, Congolese army deserters formed the M23 rebel movement. This article analyses the insurgency and other armed group activity in the eastern DRC in the light of the politics of rebel-military integration. It argues that military integration processes have fuelled militarization in three main ways. First, by creating incentive structures promoting army desertion and insurgent violence; second, by fuelling inter- and intra-community conflicts; and third, by the further unmaking of an already unmade army. We argue that this is not merely the product of a lack of political will' on behalf of the DRC government, but must be understood in the light of the intricacies of Big Man politics and Kinshasa's weak grip over both the fragmented political-military landscape in the east and its own coercive arm. Demonstrating the link between military integration and militarization, the article concludes that these problems arise from the context and implementation of integration, rather than from the principle of military power sharing itself. It thus highlights the crucial agency of politicalmilitary entrepreneurs, as shaped by national-level policies, in the production of 'local violence'.
\end{abstract}

IN THE SPRING OF 2012, THE PROTRACTED VIOLENCE in the eastern Democratic Republic of the Congo (DRC) flared up again with the launch of yet another major rebellion, soon known as M23. The group was formed after the desertion of an important faction of the former rebel group Congrès National pour la Défense du Peuple (CNDP, National Congress for the Defence of the People), who had integrated overnight into the Congolese military after a peace accord with the government, formally signed on 23 March 2009. Taking their name from this accord, the group

\footnotetext{
*Maria Eriksson Baaz (maria.eriksson-baaz@nai.uu.se) is Associate Professor and Senior Researcher at the Nordic Africa Institute, Uppsala and the School of Global Studies, University of Gothenburg, Sweden. Judith Verweijen (judith.verweijen@nai.uu.se) is a Research Fellow at the Nordic Africa Institute, Uppsala and the Conflict Research Group, Ghent University.
} 
claims that the Congolese government has failed to live up to its terms. ${ }^{1}$ In various offensives from April onwards, the M23 quickly occupied substantial parts of Rutshuru territory in North Kivu, revealing once more the operational weaknesses of the military from which they had defected.

As with other armed groups operating in the east, there are several underlying causes of the M23 rebellion. Conflict dynamics in the DRC are multilayered and armed group formation is driven by such variegated factors as inter- and intra-community conflicts around political, economic, and military influence; power disputes at and with the national centre; the general nature of the state, governance, and the political economy in the DRC; ${ }^{2}$ and, importantly, regional power politics. ${ }^{3}$ However, as we argue in this article, there is another factor underlying armed group mobilization that has so far received limited scholarly attention: the politics of rebel-military integration.

Political power-sharing agreements have become an almost standard ingredient of negotiated settlements to civil wars in Africa, as elsewhere. ${ }^{4} \mathrm{~A}$ growing number of these agreements contain clauses on military power sharing. ${ }^{5}$ Often under strong pressure from international stakeholders, several countries in sub-Saharan Africa, such as South Africa, Sierra Leone, Burundi, and the DRC, have embarked upon the seemingly adventurous path of merging former competing military forces into a single national army. ${ }^{6}$ While most of these countries closed the doors to the army after the integration of the signatories to the final peace agreement, ${ }^{7}$ the

1. M23, 'Qu'en est-il des accords de paix du 23 mars 2009 et des nouvelles revendications du M23?', M23 official website, 9 August 2012, <http://www.m23mars.org/quen-est-ildes-accords-de-paix-du-23-mars-2009-et-des-nouvelles-revendications-du-m23.html/> (21 August 2012).

2. Jean-Claude Willame, Banyarwanda et Banyamulenge: Violences ethniques et gestion de l'identitaire au Kivu (Institut Africain-CEDAF and L'Harmattan, Brussels and Paris, 1997); Paul Mathieu and Jean-Claude Willame (eds), Conflits et guerres au Kivu et dans la région des Grands Lacs: Entre tensions locales et escalade régionale (Institut Africain-CEDAF and L'Harmattan, Tervuren and Paris, 1999); Koen Vlassenroot and Timothy Raeymaekers (eds), Conflict and Social Transformation in Eastern DR Congo (Academia Press Scientific Publishers, Ghent, 2004).

3. Filip Reyntjens, The Great African War: Congo and regional geopolitics, 1996-2006 (Cambridge University Press, Cambridge, 2009); Gérard Prunier, Africa's World War: Congo, the Rwandan genocide, and the making of a continental catastrophe (Oxford University Press, Oxford, 2009).

4. Denis M. Tull and Andreas Mehler, 'The hidden costs of power-sharing: reproducing insurgent violence in Africa', African Affairs 104, 416 (2005), pp. 375-98.

5. According to Glassmyer and Sambanis, rebel-military integration has been used in a third of the peace processes since 1990. Katherine Glassmyer and Nicholas Sambanis, 'Rebel-military integration and civil war termination', fournal of Peace Research 45, 3 (2008), pp. 365-84.

6. Stephen Burgess, 'Fashioning integrated security forces after conflict', African Security 1, 2 (2008), pp. 69-91; Roy Licklider (ed.), New Armies from Old: Merging competing military forces after civil wars (Georgetown University Press, Washington, DC, forthcoming 2014).

7. With the exception of Burundi, where a remaining rebel group integrated at a later stage. See International Crisis Group, 'Burundi: réussir l'intégration des FNL' (Africa Briefing No. 63, International Crisis Group, Nairobi and Brussels, 30 July 2009). 
DRC government has opted for a continued open-doors policy. This has had profound adverse implications for conflict dynamics in the eastern DRC. In fact, seen from the angle of the politics of military integration, the M23 rebellion did not come as a surprise.

The apparent failure of rebel-military integration in the DRC raises a number of questions. Most importantly, why and how has the chosen military integration path affected conflict dynamics negatively? And why did the DRC government continue to pursue this path, despite indications of its limited effectiveness in terms of reducing violence? Drawing on 13 months of ethnographic research in and around military and rebel deployment sites in the Kivus and interviews with over 260 military staff in various parts of the country, this article demonstrates how the politics of military integration has become a crucial factor in sustaining violence in the eastern DRC. By creating incentives for insurgent mobilization, undermining the cohesion and perceived neutrality of the army, and fuelling communal conflict, it has fostered rather than diminished militarization. Both rebel groups with a more pronounced regional dimension, like the M23, and those more rooted in local tensions, such as groups of Mai Mai, must ultimately also be understood in relation to the wider politics of military integration. We argue that this politics of integration is not merely the product of the government's lack of will to address army reform and violence in the east. Rather, it must also be seen in the light of Kinshasa's weak grip over both the fragmented political-military landscape in the east and its own coercive apparatus. The article proceeds as follows: first, we provide an historical overview of military integration processes in the DRC, highlighting three distinct phases. Second, we analyse the implications of these processes for conflict dynamics in the east, focusing on three aspects: the creation of incentive structures promoting army desertion and insurgent violence; the fuelling of inter-and intra-community conflicts; and the further unmaking of an unmade army. Finally, we focus on the role of the DRC government, exploring the motives, logics, and consequences of the politics of serial rebel-military integration.

\section{The mixed results of initial military merging (2003-ca 2007)}

The Forces Armées de la République Démocratique du Congo (FARDC, Armed Forces of the DRC) was created in 2003, in the wake of a negotiated settlement that stipulated the merging of the fighting forces of all belligerents of the Second Congo War (1998-2002) into a new national army. ${ }^{8}$ The negotiation and execution of the military power-sharing part of the

8. The troop-contributing signatories, aside from the government, were the following: MLC, RCD-G, RCD-ML, RCD-N, and the various groups of Mai Mai. However, non-signatories of 
2002 Pretoria agreement was one of the most contentious and difficult issues of the DRC's peace process. It took place in an atmosphere of profound distrust and disagreements. As violence in the east continued, the commitments made by those at the negotiation table in Kinshasa were often short on credibility. Furthermore, the process was highly opaque, given that factions withheld crucial information with regard to arms caches and numbers of combatants. This tense climate turned the allocation of ranks, command, and staff positions into particularly disputed issues. In general, a generous ranks policy was applied, resulting in a disproportionate number of officers in relation to soldiers, and a general deflation of ranks, which fed frictions within the army. ${ }^{9}$ Even more contentious than the issue of ranks was the distribution of command and staff positions. Whereas the allocation of the most senior positions, specifically in the national and regional command structures, was based on a quota system that reflected declared troop numbers, the nomination of individual candidates and the distribution of non-senior positions did not follow transparent criteria. ${ }^{10}$ Predictably, this caused in-fighting and tension, especially since the stakes were very high. With official salaries being negligible, it is a position, often coupled to a specific position in a Big Man network, and not a rank, which determines one's fortune(s) and influence in the FARDC. ${ }^{11}$ Hence, the struggle for positions was a deeply political process, the outcomes of which were shaped by power games played at several levels. As a consequence, factions with little clout and lacking connections in Kinshasa lost out. These were mostly smaller factions with only a local power base, like the Mai Mai, a heterogeneous collection of rural-based militia. Realizing they would lose power and resources when leaving their local fiefs, many such groups had little appetite for becoming absorbed in the FARDC. For others who did integrate, frustration about being marginalized would later form part of their motivation to desert.

The mixing of troops led to further complications. It was to be achieved through a so-called brassage (brewing) process, which consisted of mixing fighters on an individual basis and then retraining them in integrated brigades. This process was supposed to break down former command structures and old loyalties, thus establishing a unified chain of command. Officially, brassage aimed for a geographical spread and balanced composition of the

the final accord, including the plethora of armed groups in the Ituri district, were also allowed to integrate their troops.

9. Maria Eriksson Baaz and Maria Stern, 'Making sense of violence: voices of soldiers in the Congo (DRC)', Fournal of Modern African Studies 46, 1 (2008), pp. 57-86.

10. Judith Verweijen, 'Half-brewed: the lukewarm results of creating an integrated Congolese military', in Licklider (ed.), New Armies from Old.

11. For a recent analysis of Big Man networks in African (post-)conflict societies see Mats Utas (ed.), African Conflicts and Informal Power: Big Men and networks (Zed Books, London and New York, NY, 2012). 
integrated brigades. However, these principles were not consistently adhered to and have (as we will demonstrate below) continued to be flouted in subsequent phases of integration. One of the factors contributing to this was the manipulation of the military integration process by the different troopcontributing factions. ${ }^{12}$

The military forces to be integrated were generally part of wider political-economic networks that had developed in the course of the wars. Reluctant to give up control over their spheres of influence and their constituencies, several factions sabotaged the brassage process, especially in the east. They either withheld their troops, or tried to manipulate the process, by preventing their integrated troops from being deployed far from their zones of influence or by refusing their placement under a different command chain. As a result, military integration proceeded only at a snail's pace. ${ }^{13}$ Whereas new command structures had been created in 2003, the last integrated brigade (the 18th) was only formed in 2008. Despite these setbacks, the brigades resulting from brassage were reasonably well integrated, as former affiliations gradually diminished in importance. ${ }^{14}$ However, this did not apply to the national and regional command structures. In addition, the problem of units refusing integration remained.

One of the groups dodging brassage was a part of the biggest rebel faction, the Rassemblement Congolais pour la Démocratie-Goma (RCD-G, Congolese Rally for Democracy-Goma), who had controlled most of the Kivus. Its leadership was dominated by Congolese Tutsis and Hutus, also called 'Rwandophones'. ${ }^{15}$ The RCD-G faced bleak prospects in the 2006 general elections that were to end the 'transition period'. ${ }^{16}$ Their wartime behaviour and image as a vehicle for Rwandan interests had made them unpopular. Furthermore, they feared for the security of the Tutsi community in the Kivus, a fear that was instrumentalized in order to justify their refusal to send all of their troops to brassage. At the same time, the RCD's power base, including its sources of revenue, enjoyed relative autonomy from

12. Stephanie Wolters and Henri Boshoff, 'The impact of slow military reform on the transition process in the DRC' (Situation Report, Institute for Security Studies, Pretoria, 10 July 2006).

13. Hans Hoebeke, Henri Boshoff, and Koen Vlassenroot, 'Assessing security sector reform and its impact on the Kivu provinces' (Situation Report, Institute for Security Studies, Pretoria, 26 November 2008).

14. Judith Verweijen, The Ambiguity of Militarization: The complex interaction between the Congolese armed forces and civilians in the Kivu provinces, eastern DRC (unpublished PhD dissertation, University of Utrecht, forthcoming).

15. 'Rwandophone' refers originally to Kinyarwanda speakers, encompassing Hutus and Tutsis, but has come to signify a more comprehensive ethnicized identity in the DRC.

16. Transition is put between quotation marks, as this period did not really lead to a transformation of governance, and therefore does not qualify as a 'transition'. See Timothy Raeymaekers, The Power of Protection: Governance and transborder trade on the Congo-Ugandan frontier (unpublished PhD dissertation, Ghent University, 2007), p. 31. 
Kinshasa, in part due to its strong connections to Rwanda. Consequently, parts of this group sensed they had little to gain from integration into the FARDC. ${ }^{17}$ It is from this group that the CNDP, and later, parts of M23 would issue, in both cases driven by a desire to hold on to local fiefdoms and separate spheres of power.

\section{Revolving doors in a military mess (ca 2007-9)}

As a result of the slow pace and manipulation of the integration process, the eastern DRC still swarmed with forces that were not effectively integrated after the 'transition' ended in 2006. Additionally, foreign armed forces like the Forces Démocratiques de Libération du Rwanda (FDLR, Democratic Liberation Forces of Rwanda), ${ }^{18}$ a former proxy of the Kinshasa government, occupied vast swathes of the Kivus. It also became increasingly clear that many brassage dodgers preferred to opt out on a permanent basis, and were reorganizing themselves as armed groups. This applied both to smaller Mai Mai groups, and to a part of the RCD-G.

In 2006, a Tutsi-led dissident faction of the RCD-G formally established themselves as a rebel group called CNDP under General Laurent Nkunda. This group swiftly became one of the most powerful armed groups in the DRC in military, political, and economic terms, partly as a result of Rwandan support. After a series of resounding military defeats for the government, a first attempt to integrate the CNDP into the FARDC was embarked upon in early 2007. This occurred through a process called mixage, which allowed CNDP troops to stay in or close to their stronghold in Masisi (North Kivu), while breaking integrated units down only to the battalion level. This set-up meant that mixage and the efforts to neutralize Nkunda were doomed from the beginning. It allowed him to maintain established command structures, while expanding his power and sources of income. Moreover, his brigades were operating autonomously from the 8 th Military Region (North Kivu) and were conducting military operations not controlled by the hierarchy. ${ }^{19}$ After a couple of months, it became painfully clear that the 'integration' had failed. With the mixed brigades disintegrating, the situation deteriorated, and a year of off- and- on fighting followed.

17. Jason Stearns, 'Laurent Nkunda and the National Congress for the Defence of the People (CNDP)', in Stefaan Marysse, Filip Reyntjens, and Stef Vandegiste (eds), L'Afrique des Grands Lacs: Annuaire 2007-2008 (L'Harmattan, Paris, 2008), pp. 245-67.

18. The FDLR are a rebel group run by Hutu elements of the former Rwandan government army and Interahamwe militia who fled to the DRC after the 1994 genocide.

19. For more details on the mixage process, see Stearns, 'Laurent Nkunda', and Stephanie Wolters, 'Trouble in eastern DRC: the Nkunda factor' (Situation Report, Institute for Security Studies, Pretoria, 3 September 2007). 
Meanwhile, smaller-scale armed groups also continued to proliferate. Most of these consisted of army deserters or demobilized fighters who were dissatisfied with their new positions in the post-settlement order. Many had lost influence and income in comparison to the war era. Others felt that they were discriminated against by the Kinshasa government, which they perceived to favour Rwandophones. ${ }^{20}$ Some also had little trust that the FARDC would protect their communities, as they saw the army as partisan. Given that much of the economy and the administration in the east remained strongly influenced by militarized networks, violence and armed group creation continued to be a viable way to build a power position. Furthermore, military pressure on armed groups was low. Counter-insurgency operations did not seem to be the priority of the newly elected government, nor did it dispose of a sufficiently capable or motivated army to undertake these in an effective manner. Rather, Kinshasa preferred to continue to negotiate with dissident groups, following the time-tested approach of cooption. Consequently, armed groups, including those founded by army deserters, were enticed with promises of ranks, positions, and other privileges, such as control over their former strongholds.

As we show in subsequent sections, this policy of 'many carrots with few sticks' made the (re)constitution of armed groups a rewarding business, causing some factions to move in and out of the army opportunistically. This revolving-door mechanism was also triggered by the Goma Peace Conference. At the start of 2008, the government tried to address the situation in the Kivus by arranging a grand peace conference in Goma. Sponsored by several international donors, the conference lasted over two weeks and included the CNDP as well as 21 other armed groups. However, shortly after an accord was signed, various armed groups and the DRC government mutually accused each other of violating its terms. The shaky ceasefire rapidly unravelled and the Kivus plunged into full-fledged violence again.

\section{Accelerated integration and accelerated desertion (2009-12)}

After the DRC government suffered a new series of military humiliations at the hands of the CNDP at the end of 2008, a new round of negotiations followed, again behind heavily closed doors. These talks came in the wake of a sudden rapprochement between Kinshasa and Kigali, and therefore featured strong Rwandan involvement. At the beginning of January 2009 General

20. This is clearly illustrated by the political propaganda relayed by these groups at the 2008 Goma Conference. See for example, Joseph Assanda Mwenebatu, 'Déclaration des Mai Mai de Fizi à la Conférence Nationale sur la Paix, la Sécurité et le Développement dans les Provinces du Nord-Kivu et Sud-Kivu tenue à Goma en Janvier 2008' (unpublished document, 10 January 2008). 
Bosco Ntaganda, chief of staff of the CNDP, announced that he had replaced Nkunda and that the CNDP would integrate into the FARDC. As during the 2007 mixage experiment, a fast-track military integration process was initiated without vetting or training, and without ensuring a balanced geographical deployment of integrated elements, who were broken down to company-level only. Eventually, around 6,000 troops of the CNDP and a few thousand troops of the Hutu-led Coalition des Patriotes Résistants Congolais (PARECO, Alliance of Resistant Congolese Patriots), plus a number of smaller armed groups, were integrated..$^{21}$

Since the government negotiated from a position of weakness, the price to buy CNDP 'loyalty' was high. Thus, the CNDP was awarded an impressive number of important command positions within newly created operational structures. They also obtained privileged access to lucrative areas of deployment, like those rich in natural resources, important trade routes, and border crossings. This enabled them to extend their influence far beyond the areas they controlled before integration. Furthermore, they were allowed to keep their arms caches and maintain (initially) parallel systems of taxation and administration in their fief of Central Masisi. Finally, the bulk of their forces could remain deployed in the Kivu provinces, leading them to build up a position of military dominance. ${ }^{22}$ As we demonstrate further below, the privileged treatment of the ex-CNDP created a deep-seated frustration among the other troops. It triggered renewed desertions, specifically from ex-Mai Mai, while also reinforcing the mobilization of non-integrated groups.

In brief, CNDP integration intensified power struggles within the military, within the Kivus, between the Kinshasa government and the Kivus, and, eventually, between Kinshasa and Kigali. As the ex-CNDP continued to exist as a parallel and influential structure within the FARDC, their integration became conditional upon their ongoing access to pay-offs. The subsequent situation represented a Catch-22, as reducing the ex-CNDP's influence within the FARDC would imply wresting control over their autonomous sources of revenue. Yet, it was precisely this autonomous economic base that enabled them to withstand government pressure. Essentially, therefore, the latter was held hostage.

This uncomfortable position became painfully clear when the presidential circle tried to dilute the ex-CNDP's power in the Kivus from the end of 2010 onwards. The first attempt to do so consisted of pronouncing a

21. Jason Stearns, 'North Kivu: the background to conflict in North Kivu province of eastern Congo' (Usalama Project, Rift Valley Institute, London, 2012), pp. 40-1.

22. 'Final Report of the Group of Experts on the Democratic Republic of the Congo' (UN Security Council, S/2009/206, New York, 23 November 2009), pp. 45-57; 'Final Report of the Group of Experts on the Democratic Republic of the Congo' (UN Security Council, S/2010/596, New York, 29 November 2010), pp. 42-6. 
temporary ban on mining activities, which aimed to loosen the grip military actors held over the sector. During this time they also pushed for the redeployment of a part of the ex-CNDP's troops elsewhere, with the FARDC chief of staff threatening to court-martial those refusing the orders. In 2011, yet another attempt was made to break parallel command chains, this time through a restructuring process that transformed brigades into regiments. However, none of these measures were effective: the mining ban ended up reinforcing, rather than weakening, the grip of the FARDC over the sector; ex-CNDP officers simply refused redeployment - with impunity; and the regimentation process was hijacked, strengthening instead of diminishing the ex-CNDP's influence on the FARDC command in the Kivus. ${ }^{23}$

After his contentious re-election in 2011, President Joseph Kabila renewed efforts to dismantle the ex-CNDP power network in the Kivus, partly in a bid to boost his domestic and international popularity and restore a part of his dented legitimacy. This included plans to remove General Bosco Ntaganda, for whose arrest the International Criminal Court (ICC) had issued a warrant in 2006. At the beginning of 2012, a number of reform initiatives were announced, including redeployments and changes in command. This new threat to their power position provoked a strong reaction among sections of the ex-CNDP, who mutinied, deserted, and subsequently founded the M23. The mutiny was facilitated by the parallel systems of command, revenues, and armaments the CNDP had maintained within the FARDC. ${ }^{24}$ Furthermore, it is plausible that the relative ease with which army deserters can integrate back into the FARDC, and from a better bargaining position, played a role in their decision to desert. Hence, the creation of the M23 fits into a wider pattern of revolving-door military integration that has been fed by a many-carrots-with-few-sticks approach.

Below we analyse the implications of these processes for conflict dynamics, focusing on three aspects: the effects on armed-group mobilization, the impact on conflicts between and within communities in the east, and, finally, the consequences for the armed forces in terms of cohesion and operational effectiveness.

\section{The creation of incentive structures promoting insurgent violence}

A key to understanding the impact of military integration on conflict dynamics in the eastern DRC is that it has been an ongoing process, with

23. 'Final report', S/2010/596, pp. 45-6; 'Final Report of the Group of Experts on the Democratic Republic of the Congo' (UN Security Council, S/2011/738, New York, 2 December 2011), pp. 81-3.

24. 'Final report of the Group of Experts on the Democratic Republic of the Congo' (UN Security Council, S/2012/348, New York, 21 June 2012), pp. 18-30. 
(parts of) factions alternately integrating and deserting. In combination with the many-carrots-with-few-sticks approach, this has had a profound impact on the cost-benefit calculations made by military entrepreneurs. On the one hand, it has lowered the costs of military integration drastically. Given that armed groups are allowed to integrate without handing in all their arms caches and fighters, while staying in or close to their fiefs, and while maintaining their combatants under their own command, the costs associated with military integration are low. Furthermore, the policy is easy to reverse, as desertion does not spoil the forecasts for reintegration, nor is it punished individually or through serious military pressure on groups who dropped out. On the other hand, the potential benefits of military integration continue to be significant. These include the generous distribution of (promises of) high ranks and important positions, and military and sometimes de facto administrative control over fiefdoms or lucrative zones.

As demonstrated above, the many-carrots-with-few-sticks-approach was built into military integration from the beginning. However, the balance between costs and benefits became even more skewed in subsequent military integration processes. Serial military integration gave military entrepreneurs further opportunities and incentives to turn (threats of) desertion, non-integration, or violence into a political resource, thus reinforcing their negotiation position. This 'rents of violence syndrome' ${ }^{25}$ was made extremely clear by the 2008 Goma Conference. In addition to giving military and political entrepreneurs an opportunity to voice their demands, get international attention and legitimacy, and profit from generous per diems and other benefits packages, this conference raised hopes of access to desirable positions in the administration and military. These (potential) benefits were so enticing that dormant armed groups, like Mudundu 40, were promptly revived and new ones created. ${ }^{26}$ In many cases, the initiative for renewed mobilization was taken by commanders who had failed to obtain favourable positions during brassage.

Commander Mahoro is a case in point. He occupied a high position in the Mai Mai brigade of Nyakiliba in South Kivu during the Second War, but received only the rank of major and a negligible position after brassage. When he learned of the Goma Conference, he decided to launch his own movement: the Mai Mai Mahoro. Profiting from the revenues of the conference, he, like many other groups, intensified recruitment, in order to inflate their numbers before integration. In this way, he hoped to obtain higher ranks and better positions. In Mahoro's case, this strategy worked with regards to rank, and he was made full colonel after his 2009 integration into

25. Tull and Mehler, 'Hidden costs of power-sharing', p. 391.

26. Koen Vlassenroot and Timothy Raeymaekers, 'Kivu's intractable security conundrum', African Affairs 108, 432 (2009), pp. 475-84. 
the FARDC. However, failing again to obtain an influential position, he resumed armed group activity. In May 2011, he deserted and joined the Mai Mai Mushombe in the hills of Uvira territory (South Kivu). His main motivation for this, as he declared, was to obtain a better function in the FARDC and have his rank as full colonel officially recognized. ${ }^{27}$

In sum, the pursued approach to military integration has profoundly skewed the balance between the costs and benefits of army integration, turning it into a political resource for military entrepreneurs and the wider political-economic networks in which they are embedded. Of specific importance in this respect has been the lack of credible guarantees to sanction defectors, often highlighted in the literature on civil war settlements as one of the main obstacles to implementation. ${ }^{28} \mathrm{~A}$ telling example here is that of Lt Col Kifaru, an ex-PARECO commander who deserted with around 200 troops from the regimentation centre of Kananda (Fizi, South Kivu) in June 2011. What pushed him to desert was that he knew he would not be given the position of regiment commander, having demonstrated his inability to run the 43rd sector in Fizi. Frustrated and incensed, Kifaru and his troops fled into the mountains, committing considerable human rights violations on the way. However, under pressure from ex-CNDP circles, investigations into the committed abuses were halted and Kifaru was reintegrated into the FARDC, without any form of sanction. By contrast, and to the astonishment of many, he was made commander of the 111 th regiment. Hence, he was essentially rewarded for his desertion, regardless of the human rights abuses committed by his troops.

Many in the military who had previously served in Kifaru's sector ascribed this impunity to his 'Rwandophone' background. In the words of one lieutenant: 'A Rwandophone can kill, assassinate, rape, and do whatever he wants. But if it were me, a Congolese, Moreno Ocampo [Prosecutor of the ICC] would be informed the same day. ${ }^{29}$ This interpretation was widely shared by civilians in this area, reflecting another effect of the military integration route taken, namely the fuelling of prevailing interand intra-community conflicts.

\section{The fuelling of inter-and intra-community conflicts}

The unbalanced composition of the brigades created after the 2009 fast-track integration, and their deficient geographical distribution, came to fuel

27. Interview, Mai Mai commander Mahoro Kitay Ngombarufu, Bijombo-Ishenge, 18 November 2011.

28. Monica Duffy Toft, Securing the Peace: The durable settlement of civil wars (Princeton University Press, Princeton, NJ, 2009), p. 2.

29. Interview, FARDC lieutenant, Luberizi, 7 November 2011. 
existing inter-and intra-community tensions in the Kivus. ${ }^{30}$ Some of these brigades consisted of a majority of ex-CNDP or ex-PARECO troops, leading to a domination by 'Rwandophones'. In areas largely populated by self-styled 'autochthonous' populations, who have come to be defined antagonistically towards 'Rwandophones', this allowed local ethnic entrepreneurs to mobilize support by brandishing hostile rhetoric. ${ }^{31}$ One manifestation of this was the revival of the 'infiltration' hypothesis, leading to a recycling of the old joke of calling the FARDC 'Forces Armées Rwandaises en RDC' (Rwandan Armed Forces in the DRC). Moreover, 'Rwandophone' soldiers were increasingly portrayed as pawns of Rwandan interests or simply as Rwandan nationals, a vanguard for the occupation and dismemberment of the Congo seeking to expel populations from their land and grab their natural resources. In various places in the Kivus, Mai Mai groups capitalized upon CNDP integration by inflating the security threats it entailed. For example, in a 2011 political manifesto, the Fizi-based Mai Mai Yakutumba listed as 'recommendations' that 'the foreign troops camouflaged as FARDC (CNDP, FDLR) go back to their country of origins', as each entry of foreign troops is 'a provocation and a threat of war'. ${ }^{32}$ Thus, the perceived lack of neutrality of the army exacerbated locally experienced security dilemmas, with ethnic entrepreneurs harnessing military integration policies for their own agendas.

However, the ways in which military integration has reinforced inter-and intra-community tensions must also be ascribed to the military's tendency to be drawn into dispute settlement and other local governance issues. Military integration without redeployment of troops has allowed many units to stay close to their constituencies and established political-economic networks. In the face of weak civilian governance, this increases the likelihood of military interference in civilian affairs, especially dispute resolution. ${ }^{33}$ This is particularly evident in relation to conflicts about property rights, political influence, and land or other natural resources, ${ }^{34}$ but also in disputes concerning private and family affairs. ${ }^{35}$ While both locally

30. International Crisis Group, 'Congo: no stability in Kivu despite a rapprochement with Rwanda' (Africa Report No. 165, International Crisis Group, Nairobi and Brussels, 16 November 2010).

31. For more details on the autochthony discourse, see Stephen Jackson, 'Sons of which soil? The language and politics of autochthony in eastern DRCongo', African Studies Review 49, 2 (2006), pp. 95-123.

32. Mai Mai Reformé, Groupe Alleluia/Yakotumba, Notre cahier de charge adressée à son excellence monsieur le Président de la République et Chef de l'Etat de la République Démocratique du Congo à Kinshasa' (unpublished document, 5 February 2011).

33. Verweijen, Ambiguity of Militarization.

34. See for instance, Nicholas Garrett, Sylvia Sergiou, and Koen Vlassenroot, 'Negotiated peace for extortion: the case of Walikale territory in eastern DR Congo', Fournal of Eastern African Studies 3, 1 (2009), pp. 1-21. For examples of the role played by ex-CNDP officers in land conflicts in Masisi, see 'Final report', S/2010/596, pp. 73-4.

35. Judith Verweijen, 'Military business and the business of the military in the Kivus', Review of African Political Economy 40, 135 (2013), pp. 67-82. 
recruited troops and those coming from elsewhere engage in such forms of public and private regulation, our research shows that the involvement of the first is more likely to exacerbate tensions, given the specific links they have to certain communities and established elites. This illustrates the destabilizing effects of military integration without redeployment and with an unbalanced mix of troops. As discussed below, this approach has also had a detrimental impact on dynamics within the military.

\section{The further unmaking of an unmade army}

The roots of the FARDC's notorious combat weakness go far beyond processes of military integration. This phenomenon must be considered in the light of both the country's military history, and the nature of its state apparatus. Being an integral part of the Congolese state, the FARDC reflects all the particularities, which some would call dysfunctions, of its administration. In the military realm, the weak institutionalization of the state in rational-legal terms translates into irregular and non-centralized command chains and inefficient systems of logistics, communications, and intelligence. These features were also found among the FARDC's predecessor forces, creating a long tradition of erratic military functioning. ${ }^{36}$ Moreover, and similar to work in the administration, ${ }^{37}$ service in the FARDC is characterized by a relative lack of material (salaries) and non-material (social status, recognition) rewards, ${ }^{38}$ which has lowered soldiers' enthusiasm for risking their lives in combat. In combination with the workings of Big Man logics, which render power projection dependent on the distribution of (access to) resources, these low official rewards foster a constant need for revenue generation. As a consequence, the FARDC is simply not geared towards reaching operational effectiveness.

Whereas the roots of irregular military functioning are multiple and deep, rebel integration processes have contributed to the further unmaking of an already unmade army. The lack of retraining and redeployment has nurtured parallel structures of command, thus undermining centralized command and control. While brassage managed to break down some of the old allegiances, the fast-track integration of 2009 fostered a continuation of

36. Crawford Young and Thomas Turner, The Rise and Decline of the Zairian State (University of Wisconsin Press, Madison, WI, 1985), pp. 248-75.

37. Theodore Trefon, 'Public service provision in a failed state: looking beyond predation in the Democratic Republic of Congo', Review of African Political Economy 36, 119 (2009), pp. 9-21.

38. For more details on the social conditions within the FARDC and their consequences, see Maria Eriksson Baaz and Maria Stern, 'The complexity of violence: a critical analysis of sexual violence in the Democratic Republic of Congo (DRC)' (Sida Working Paper on genderbased violence, Sida, Stockholm, 2010). 
strong separate patronage networks and command chains. ${ }^{39}$ As one officer put it: 'at present, there are carrots, onions, potatoes; the FARDC is a true bouillabaisse'. ${ }^{40}$ This has contributed to what is called in militarysociological terminology 'low social and task cohesion', which are crucial for combat motivation and performance. ${ }^{41}$

While these parallel power networks by no means simply follow ethnic identification, the 2009 integration of the CNDP reinforced the 'autochthon/Rwandophone' cleavage within the military. ${ }^{42}$ In fact, it fuelled antagonism up to the point that some soldiers came to speak of a 'Cold War' within the military. Clearly, these divisions further undermine cohesion and promote subordination, as troops are less willing to obey orders from superiors they suspect will only defend the parochial interest of their own community. Furthermore, the failure to break down old allegiances has been manifested in the repeated leaking of military intelligence. ${ }^{43}$ Integrated forces, which are often closely connected to non-integrated remnants, have tended to be generous with the diffusion of military information. These divided loyalties have further demoralized troops, who are often painfully aware that they are fighting an enemy often warned of a forthcoming attack.

Importantly, this demoralization has been markedly intensified by the many-carrots-with-few-sticks approach, which has created feelings of unpredictability and unfairness within the ranks of the FARDC. This has serious implications for combat motivation. While desertion is considered the gravest form of indiscipline in other armies, the Congolese authorities, as demonstrated above, have regularly welcomed defected units and commanders back into the fold, often even rewarding them with better opportunities. Logically, the propensity to excel in fighting sharply diminishes when there is a real chance that today's enemy is tomorrow's commander. As one captain explained:

If I am sent back again [to the 'front']? Then I will desert. I will not go. Why should I risk my life? What do I get? Nothing. No salary, no ration, no nothing. ... Also, the people you fight today, tomorrow the superiors tell you they are integrated - that they are your colleagues. And you find some loser with no training becoming your commanding officer. But we

39. This confirms findings by Gaub that mixing units at lower levels will result in higher cohesion. See Florence Gaub, Military Integration after Civil Wars: Multi-ethnic armies, identity, and post-conflict reconstruction (Routledge, London and New York, NY, 2011).

40. Interview, FARDC Major, Lemera, 19 March 2010.

41. See, for example, Leonard Wong, 'Combat motivation in today's soldiers', Armed Forces E Society 32, 2 (2006), pp. 659-63; Robert. J. MacCoun, Elizabeth Kier, and Aaron Belkin, 'Does social cohesion determine motivation in combat? An old question with an old answer', Armed Forces \& Society 32, 2 (2006), pp. 646-54.

42. 'Final report', S/2011/738, pp. 89-90.

43. While leaks of intelligence are also common among other troops, being both a business in itself and facilitating business, our field research indicates that the threshold for defusing information is lower among weakly integrated troops. 
- we get nothing. You fought - but in the end you turn out to be the loser/idiot [yo muntu obimi nyuma.$^{44}$

In short, by further unmaking an already unmade FARDC, military integration has generated a vicious circle. Having an army that is unable and unwilling to defeat or even deter, has encouraged the DRC government to coopt armed groups through generous offers. This again, has undermined the military's operational effectiveness, and occasioned the proliferation of armed groups. The (re)integration of these groups, in turn, has further weakened the military. In this way, flawed and serial military integration has fuelled, rather than defused, the militarization of the Kivus.

\section{Understanding the politics of military integration}

Why then have these harmful policies and processes been allowed to continue for so long? Why did the Kabila government hold on to the messy policy of ongoing military integration and endless negotiations with everproliferating armed groups? The dominant interpretation, widely circulating among external actors involved in Security Sector Reform (SSR) in the DRC, is that the government lacks 'political will' to engage in real army reform and stabilize the east. ${ }^{45}$ According to this logic, failed military integration - like slow progress with SSR generally - is a result of the government cunningly masquerading as genuinely committed to reform, while consciously sabotaging it. ${ }^{46}$ The purported reasons provided in this line of argument are that a strong army could destabilize the regime and that key actors in government circles profit from a continuation of (low-intensity) conflict in the eastern provinces.

Certainly, lukewarm government commitment is a part of the problem. The divide-and-rule policy towards the army has a long tradition in the Congo, ${ }^{47}$ as in other places where a coherent army has been judged

44. Interview, FARDC captain, Kinshasa, April 2009.

45. See, for example, Henri Boshoff, Dylan Hendrickson, Sylvie More, and Thierry Vircoulon, 'Supporting SSR in the DRC: between a rock and a hard place. An analysis of the donor approach to supporting security sector reform in the Democratic Republic of Congo' (Netherlands Institute of International Relations Clingendael, The Hague, 2010); ASADHO et al., 'The Democratic Republic of Congo: taking a stand on security sector reform' (ASADHO et al., New York, NY, 16 April 2012).

46. See Theodore Trefon, Congo Masquerade: The political culture of aid inefficiency and reform failure (Zed Books, London and New York, NY, 2010). For a critical discussion, featuring Congolese voices, see Maria Eriksson Baaz and Maria Stern, 'Willing reform? An analysis of defence reform initiatives in the DRC', in Arne Bigsten (ed.), Globalization and Development: Rethinking interventions and governance (Routledge, New York, NY, forthcoming 2013).

47. Jacques Ebenga and Thierry N'Landu, 'The Congolese National Army: in search of an identity', in Martin Rupiya (ed.), Evolutions and Revolutions: A contemporary history of militaries in Southern Africa (Institute for Security Studies, Pretoria, 2005) pp. 63-84. 
undesirable. ${ }^{48}$ Moreover, it is clear that key actors within the military and political establishment in Kinshasa benefit from the profits reaped by military entrepreneurs in the east. ${ }^{49}$ It is reasonable to assume that this contributes to a lukewarm commitment to army institutionalization and stability. However, in addition to being based on a simplistic notion of 'political will' as either existing or not, as if it was a binary rather than a continuum, assuming that failed military integration is simply a result of Kabila's efforts to harvest the fruits of continued disorder is to obscure a range of important factors.

First, such assumptions ignore the difficulties posed by projecting central state power in a strongly fragmented political-military environment, without a tradition of direct administrative intervention. Historically, Kinshasa has exercised power over the Kivus through intermediaries and the cooption and integration into Big Man networks of local power holders. This has always been an 'archipelago-like rule', in which more direct administrative intervention was limited to strategic and resource-rich areas. ${ }^{50}$ Hence, if placed in a historical perspective, military integration policies can be seen to reflect a continuation of a time-tested strategy of patronage-based indirect rule.

Second and relatedly, the nature of the army renders elusive the straightforward implementation of any military policy - even when desired by Kinshasa. An important channel of access to state resources, economic influence, and political power, the FARDC is a collection of permanently competing power networks that is subject to strong centrifugal tendencies. The constant balancing act that is required for maintaining this army intact sharply reduces Kinshasa's room for manoeuvre. In order to maintain a dominant position, the presidential circle has opted for divide-and-rule techniques and frequent rotations of office. Ongoing rebel-military integration strongly promotes the power fluctuations needed for these strategies. ${ }^{51}$ From this angle, military integration can be seen as part of a strategy not to destabilize, but rather to retain a measure of control within the FARDC although this has worked only to a limited extent.

Third, military realities have sharply reduced the government's options to defeat armed groups. This is not only related to the combat weakness of the FARDC elaborated on above, or its collusion with rebel groups. The

48. Herbert M. Howe, Ambiguous Order: Military forces in African states (Lynne Rienner Publishers, Boulder, CO, 2001).

49. For example, the involvement of FARDC Chief of Staff Gabriel Amisi in mining operations in the Kivus has been well documented. See 'Final Report', S/2011/738, pp. 62, 116, $120,129-30$.

50. Denis Tull, 'A reconfiguration of political order: the state of the state in North Kivu (DR Congo)', African Affairs 102, 408 (2003), pp. 429-46.

51. Verweijen, Ambiguity of Militarization. 
difficult terrain of eastern DRC seriously limits the effectiveness of military operations. Rebels can easily withdraw into the vast swathes of isolated, infrastructure-less dense forest and hills that cover much of the east. Counter-insurgency efforts across the globe have amply demonstrated the pitfalls of such combat theatres, even when disposing over vast and state-of-the-art military resources. ${ }^{52}$ In this light, it is perhaps understandable that military decision makers have continued to prefer cooption and to rely occasionally on proxies with much more situational awareness. Certainly, that strategy has further added to the volatility of the military situation.

Fourth, the dominant discourse of a lack of 'political will' focuses on the supposed benefits of continuing conflict and tends to neglect the latter's political costs for the government. As demonstrated in the 2011 elections, the unpopular strategy of CNDP integration and ongoing violence led to a sharp fall in electoral support for Kabila in the east. ${ }^{53}$ As highlighted above, Kabila was also pushed to act against CNDP dominance by diminished domestic and international legitimacy. Furthermore, the strong position of the CNDP in the Kivus posed a threat to the formal and informal interests of the presidential patronage network. For these reasons, it is not likely that Kinshasa struck an integration deal with the CNDP merely to let them entrench their power position. Rather, as indicated by Jason Stearns, this policy reflected a longer-term strategy to gradually dismantle CNDP power, hoping that the splits within the CNDP caused by the ousting of Nkunda would facilitate the process. ${ }^{54}$ We have already described some of the actions that form part of this strategy - such as the 2010 mining ban, orders of redeployment, and the regimentation process.

Certainly, Rwanda's diverse interests in the Kivus have hampered the implementation of this strategy. Beyond shaping the modalities of CNDP integration, support from elements in Kigali also facilitated the M23 rebellion, and has been instrumental in its military advances, including the taking of Goma in November 2012. ${ }^{55}$ Yet, as Stearns points out, the

52. See Robert Asprey, War in the Shadows: The guerilla in history, Vol. 2 (iUniverse, Bloomington, IN, 2002).

53. Whereas Kabila obtained 96 percent of the votes in North Kivu and 98 percent in South Kivu during the run-off of the 2006 elections, in 2011, his support had shrunk to 39 and 45 percent respectively, in spite of extensive rigging. Data on the 2006 elections was obtained from Herbert Weiss, 'Voting for change in the DRC', fournal of Democracy 18, 2 (2007), pp. 138-51, p. 148. Data for 2011 from the National Independent Electoral Commission of the DRC, 2011, <http://www.ceni.gouv.cd/resultats.aspx> (6 June 2013).

54. Jason Stearns, 'From CNDP to M23: The evolution of an armed movement in eastern Congo' (Rift Valley Institute, Usalama Project, 2012).

55. 'Letter dated 26 November 2012 from the Coordinator of the Group of Experts on the DRC addressed to the Chairman' (Security Council Committee, S/AC.43/20 12/NOTE.64, New York, 27 November 2012). 
CNDP 'was never a Rwandan puppet' ${ }^{56}$ and CNDP officers have had rather uncomfortable and distrustful relations with Rwanda. Hence, Rwandan involvement is just one part of the story of CNDP (dis)integration and its partial rebirth in the M23. Rather than being an 'armed group apart' operating only through regionally determined logics, the CNDP's trajectory also strongly reflects the impacts of Big Man politics and military integration policies as shaped by the DRC government.

Finally, it should be pointed out that the somewhat nebulous 'lack of political will' argument tends to obscure the shared responsibility of international donors. The latter have largely supported the DRC's bumpy road of military integration, with the MONUSCO, for example, carrying out joint military operations with newly integrated troops who were not retrained and not redeployed. Donor countries providing bilateral military assistance also did little to exert influence on integration processes in the east. For example, they could have pushed for a certain quota of newly integrated troops in the units they were training, or made continued support depended on the redeployment of troops out of the Kivus. However, driven largely by a desire to enhance their own visibility, external actors have directed their efforts to easy interventions with clear measurable output, such as various forms of training. Furthermore, they have focused on short-term and quantifiable indicators of 'stabilization' - like numbers of integrated rebel soldiers - while closing their eyes to the long-term negative consequences of military integration processes.

\section{Concluding reflections}

This article demonstrates the detrimental effects of the erratic military integration process embarked upon in the DRC. By creating incentives for insurgent violence, aggravating inter-and intra-community conflicts, and further unmaking an already unmade army, it has fostered the proliferation of armed groups. Our analysis highlights what Dennis Tull and Andreas Mehler have called the 'demonstration effects' of power-sharing agreements. ${ }^{57}$ It shows how military power sharing was turned into a bargaining chip for military entrepreneurs, and how this motivated dissatisfied and marginalized (former) officers to create new armed groups.

However, we are not suggesting that these effects were produced through the mere integration of rebel groups into the army. Rather, our conclusion is that the problems with the DRC's military integration trajectory are to a large extent located in the way integration policies were shaped and played out on the ground. Of particular importance in this respect has been the

56. Stearns, 'From CNDP to M23', p. 96.

57. Tull and Mehler, 'Hidden costs of power-sharing', p. 375. 
many-carrots-with-few-sticks approach, epitomized by the overly generous treatment of integrated troops and a lack of punishment for defectors. The main elements of this approach included: serial integration without the threat that the door to the army would ever be closed, a lack of retraining and redeployment of integrated troops, a mild approach to parallel power structures and command chains, and, finally, an unbalanced composition of units which undermined belief in the military's neutrality. Our analysis therefore supports the conclusion reached by Katherine Glassmyer and Nicholas Sambanis that while military integration does not appear to be an effective peace-building tool, the problems are located to a large extent in the structure and implementation of military power-sharing agreements, rather than in the principle of military power sharing itself. ${ }^{58}$

However, we also concur with René Lemarchand that it is not only in the technicalities and modes of implementation of power sharing that explanations for its outcomes must be sought: the socio-political context, including geopolitics, plays a crucial role too. ${ }^{59}$ In the case of the DRC, the task at hand was severely complicated by the fragmented political-military environment, the strong trans-border orientation and local rootedness of some of the factions, the low degree of institutionalization of the state, and, finally, the backdrop of ongoing inter- and intra-community conflicts in the east. Regardless of the design of power-sharing deals, their implementation in such conditions is, as Lemarchand rightly points out, 'a Sysiphean job'. ${ }^{60}$ In sum, both the mechanics of military power-sharing deals and the context in which they are implemented matter for their outcomes. More successful experiences with military integration elsewhere seem to corroborate this conclusion. $^{61}$

By emphasizing the ways in which military integration has fuelled conflict and the proliferation of armed groups, our research also calls for a greater recognition of the crucial agency of political-military entrepreneurs, as well as of how this agency is shaped by national-level policies. These insights are particularly useful for research efforts exploring 'local violence and conflicts'. ${ }^{62}$ Often grounded in a reification of 'the local', some of this research tends to downplay how strongly dynamics at supra-local scales, including the agency of political-military entrepreneurs embedded in nationally and regionally operating networks, shape violence defined as 'local'. As argued by Stathis Kalyvas, violence in internal conflicts is often the joint product of

58. Glassmyer and Sambanis, 'Rebel-military integration'.

59. René Lemarchand, 'Consociationalism and power sharing in Africa: Rwanda, Burundi, and the Democratic Republic of the Congo', African Affairs 106, 442 (2006), pp. 1-20.

60. Ibid., p. 20.

61. Licklider, New Armies from Old; Gaub, Military Integration.

62. See Séverine Autesserre, The Trouble with the Congo: Local violence and the failure of international peacebuilding (Cambridge University Press, Cambridge, 2010). 
local and supra-local actors, with the latter providing crucial incentives to convert local conflicts into violence. ${ }^{63}$ It is important to recognize that political-military entrepreneurs like Mahoro, Yakutumba, or Ntaganda do not merely draw upon and 'voice' existing grievances, but heavily contribute to their inflation, partly under the influence of incentives derived from national-level policies, including military integration. In brief, analysing the crucial agency of political-military entrepreneurs, and how their actions are shaped by supra-local factors, is essential for understanding conflict dynamics and violence that play out at the local level, but of which the causes and effects are not necessarily predominantly 'local'.

The central question now is how the DRC government and foreign donors will deal with the volatile legacy of flawed military integration policies. While the military integration route taken is just one factor in a wide array of processes producing insurgent mobilization and violence, it is clear that a failure to break the vicious circle resulting from these policies will encourage a further militarization of the east, as violence will continue to be convertible into political and military benefits. Moreover, such a failure will hamper further efforts to cook the bouillabaisse, and without more effective defence reform the longer-term prospects for the demilitarization of the eastern DRC will look even bleaker.

63. Stathis Kalyvas, The Logic of Violence in Civil War (Cambridge University Press, Cambridge, 2006). 